\title{
Continuous long-term array analysis of seismic records observed during the 2011 Shinmoedake eruption activity of Kirishima volcano, southwest Japan
}

\author{
Haruhisa Nakamichi*, Yoshiko Yamanaka, Toshiko Terakawa, Shinichiro Horikawa, Takashi Okuda, and Fumihito Yamazaki \\ Earthquake and Volcano Research Center, Graduate School of Environmental Studies, Nagoya University, Nagoya 464-8601, Japan
}

(Received October 30, 2012; Revised January 16, 2013; Accepted March 4, 2013; Online published July 8, 2013)

\begin{abstract}
We deployed a seismic array at a site $5 \mathrm{~km}$ east of Shinmoedake volcano, in the Kirishima volcanic complex of southwest Japan, five days after the sub-Plinian eruption on 26 January, 2011. The array record between February and September 2011 included explosion earthquakes and episodes of weak continuous tremor during eruption periods. We estimated slownesses and back azimuths of seismic waves on a sliding 1-min window using the semblance method. The slownesses of the weak continuous tremor clustered within the range $0.2-0.8$ $\mathrm{s} / \mathrm{km}$, consistent with a mix of body and surface waves. A probabilistic approach based on a grid search was used to estimate the source locations of the explosion earthquakes and weak continuous tremor. The sources of the explosion earthquakes were beneath the crater at depths of $-0.5-1 \mathrm{~km}$ above sea level, while the source of the weak continuous tremor was beneath the northern part of Shinmoedake at depths between $1 \mathrm{~km}$ below sea level and $1 \mathrm{~km}$ above sea level. This latter region corresponds to a shallow low-resistivity layer, suggesting that hydrothermal processes are more plausible than magmatic processes as the generating mechanism of the weak continuous tremor.
\end{abstract}

Key words: Explosion earthquake, volcanic tremor, seismic array, semblance analysis.

\section{Introduction}

The Kirishima volcanic complex is a group of more than 20 volcanoes in southern Kyushu Island, Japan, of which at least 3 volcanoes have historical eruptions and more than 10 have been active during the past 22,000 years (Imura, 1992, 1994). Shinmoedake volcano, in the Kirishima group, has documented eruptions in 1716, 1717, 1771, 1822, 1959, 1991, 2008, 2009, and 2011. The 2011 eruptions began as a small phreato-magmatic eruption on 19 January that was followed by a sub-Plinian eruption on 26 January, with an eruption column reaching more than an elevation of $7 \mathrm{~km}$ (Hashimoto et al., 2012). Explosive eruptions started on 28 January and occurred several times during the first half of February. The largest of these was on 1 February, associated with intense pressure waves affecting the residential area around Shinmoedake, and the eruption plume reached over 3 km (Japan Meteorological Agency, 2012a). From December 2009 to just before the 2011 Shinmoedake eruptions, inflation of the Kirishima group was observed by a GPS network (Japan Meteorological Agency, 2012b). Deflation of the volcano was observed subsequently from 26 January to 1 February (Japan Meteorological Agency, 2012b). The modeled pressure sources of inflation and deflation were $5 \mathrm{~km}$ northwest of the summit crater of Shinmoedake at

\footnotetext{
*Now at Sakurajima Volcano Research Center, Disaster Prevention Research Institute, Kyoto University, Kagoshima 891-1419, Japan.

Copyright (c) The Society of Geomagnetism and Earth, Planetary and Space Sciences (SGEPSS); The Seismological Society of Japan; The Volcanological Society of Japan; The Geodetic Society of Japan; The Japanese Society for Planetary Sciences; TERRAPUB.
}

doi:10.5047/eps.2013.03.002 depths of 7.5 and $8.5 \mathrm{~km}$, respectively (Fig. 1) (Japan Meteorological Agency, 2012b). Inflation resumed after 1 February and continued until November 2011(Japan Meteorological Agency, 2012b). Explosive and non-explosive activity mainly occurred between early February and the middle of April, and several non-explosive eruptions occurred in late June and from late August to early September 2011 (Japan Meteorological Agency, 2012a). No eruptions have been reported since September 2011. It is important to reveal the magmatic process below the volcano for the period from the early stage of the eruptive activity to the last eruption.

Volcanic tremor is a seismic signal commonly observed at active volcanoes during quiescent and eruptive stages (e.g., Chouet, 1996; Konstantinou and Schlindwein, 2002). Various models have been invoked to explain its source mechanisms (e.g., Chouet, 1986; Julian, 1994; Jellinek and Bercovici, 2011), all involving interaction between hydrothermal or magmatic fluids and their host rocks. Explosion earthquakes are seismic signals excited by explosivetype (e.g., Vulcanian or Plinian) eruptions (e.g., Kanamori et al., 1984; Nishimura and Hamaguchi, 1993; Tameguri et $a l ., 2002)$. Therefore, the quantitative analysis of seismicity is a fundamental step toward a better understanding of the dynamics of volcanic processes.

The first step is to locate the origin of seismic signals from volcanoes. Because of the lack of clear body-wave phase arrivals and the rapid loss of signal coherence with distance, tremor and explosion earthquakes cannot be precisely located using conventional hypocenter determination methods based on phase arrivals. However, seismic arrays have been used successfully to locate tremor and explosion earthquake sources at a number of volcanoes, such as 


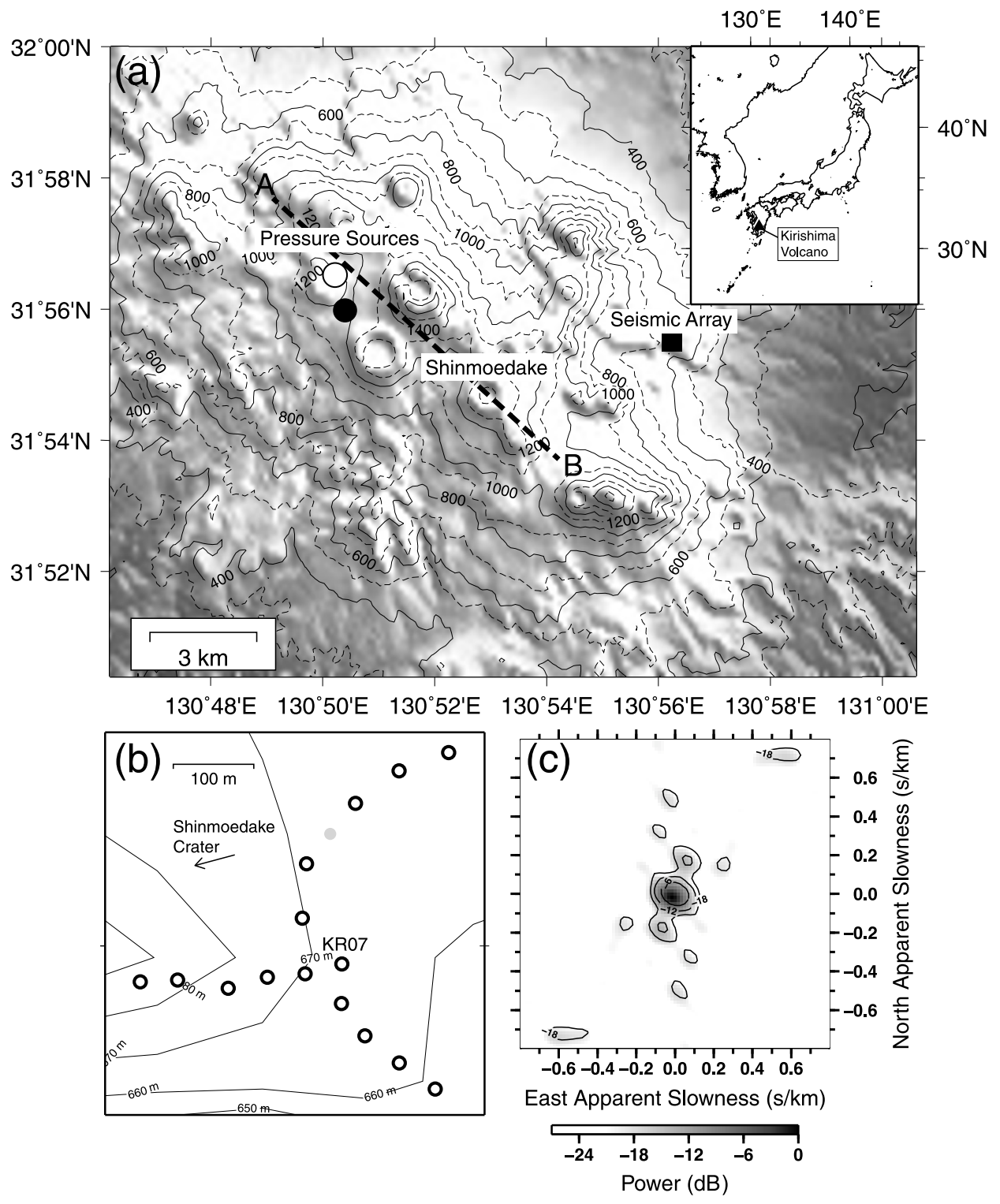

Fig. 1. (a) Location of Shinmoedake volcano, in the Kirishima volcano group, and the seismic array used for this work. The inset shows the study site location in southwest Japan. The contour interval is $100 \mathrm{~m}$. Solid and open circles show inflation and deflation pressure sources, respectively, estimated from GPS data (Japan Meteorological Agency, 2012b). The inflation occurred from 1 December, 2009, to 15 January, 2011, before the 2011 eruption, and the deflation was associated with the sub-Plinian eruption of 26 January, 2011. A conceptual model (Fig. 12) is illustrated along the approximate orientation of the cross-section AB. (b) Configuration of the seismic array (open circles). The station marked with a gray circle was not used due to a timing problem. (c) Beam-forming array response at $2.5 \mathrm{~Hz}$ for east and north components of the slowness from -0.8 to $0.8 \mathrm{~s} / \mathrm{km}$.

Colima (Palo et al., 2009), Etna (Di Lieto et al., 2007), Hawaii (Goldstein and Chouet, 1994; Almendros et al., 2001b), Izu-Ohshima (Furumoto et al., 1990), and Stromboli (Chouet et al., 1997; Saccorotti et al., 1998; La Rocca et al., 2004). We deployed a seismic array to observe and locate tremor episodes and explosion earthquakes of Shinmoedake volcano, beginning after the sub-Plinian eruption of 26 January, 2011, and continuing to the present.

In this paper, we report our array analysis of continuous waveform data from the period February to September 2011 to detect coherent waves from the volcano. Using a probabilistic method to locate explosion earthquakes and tremor, we offer some insight into the probable source process of tremor. Given that explosion earthquakes can be assumed to originate in the shallow part of the erupting crater, we also evaluate the location of tremor by comparison with the location of explosion earthquakes.

\section{Seismic Array Observation and Data}

We deployed a small-aperture seismic array, consisting of 16 stations, on the east flank of the Kirishima cluster on 3031 January, 2011, at a site $5 \mathrm{~km}$ east of the active crater of Shinmoedake (Fig. 1). The site has a relatively smooth topography with gentle slopes, allowing the array to be set up on a roughly planar ground surface. The elevations of seismometers are between $660 \mathrm{~m}$ and $700 \mathrm{~m}$ above sea level. The aperture of the array is $400 \mathrm{~m}$. The $40 \mathrm{~m}$ difference in sensor elevation is not significant for seismic array analysis as it is an order of magnitude smaller than the aperture. The relative positions of all array components were determined by GPS with an accuracy on the order of $10^{-2} \mathrm{~m}$, and the precision of their absolute locations was $0.5 \mathrm{~m}$. Each station 
(a) 2011/02/01 23:19 $15 \mathrm{~s}$

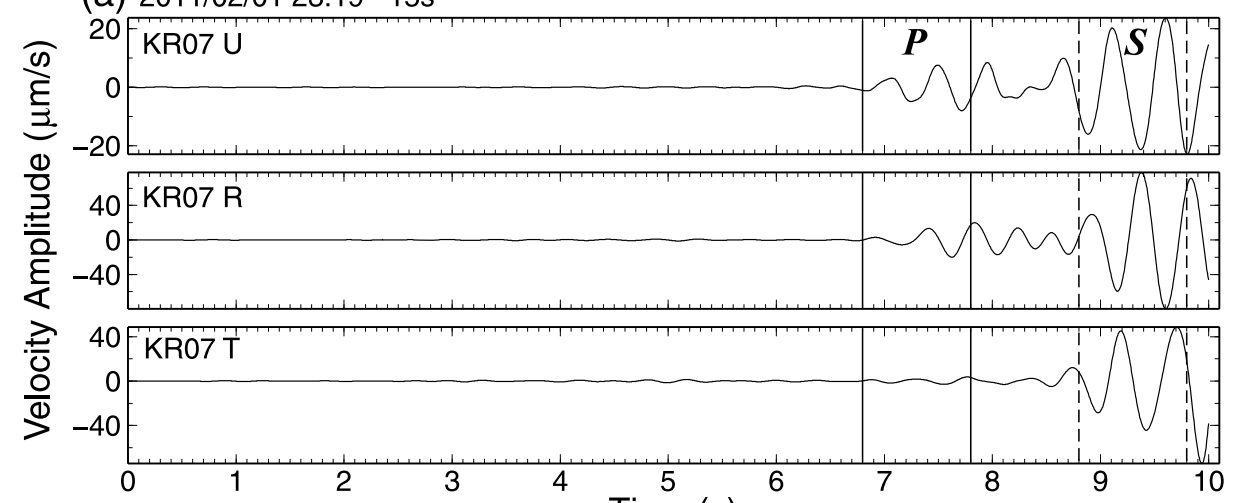

(b)
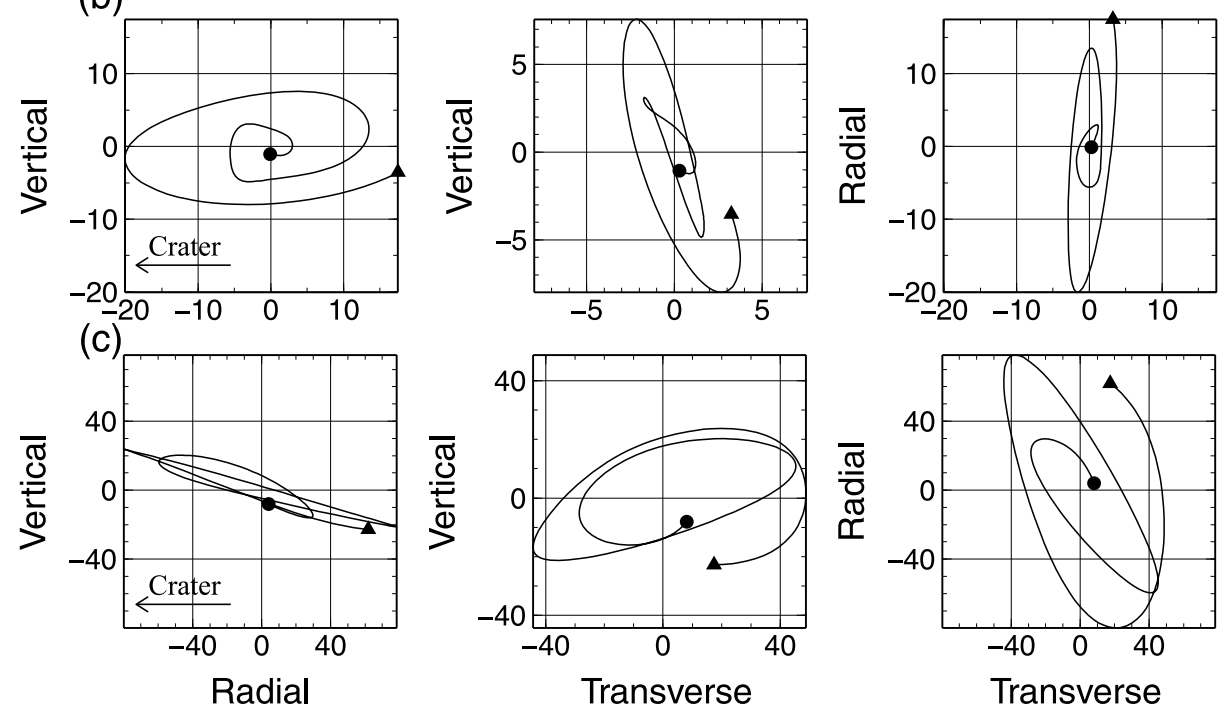

Fig. 2. Waveforms and particle motions recorded by the KR07 station (location in Fig. 1) filtered in the 2-3 Hz band for the beginning part of the explosive event at 23:19 JST on 1 February, 2011. (a) Filtered vertical, radial, and transverse waveforms. The radial direction is from the crater to the station; the transverse direction is perpendicular to the radial direction and clockwise. Particle motions of the signals within the windows marked by solid lines ( $P$ wave) and dashed lines ( $S$ wave) are plotted in (b) and (c), respectively. Particle trajectories start at the circles and end at the triangles. (b) The left panel, where vertical motion is plotted against radial motion, displays $P$ wave motion with subhorizontal incidence. (c) The left panel, where vertical motion is plotted against radial motion, displays $S$ wave motion. The middle and right plots (vertical-transverse and radial-transverse) show that both $S V$ and $S H$ components were present in the wavefield.

has a three-component Sercel L-22D seismometer with a natural frequency of $2 \mathrm{~Hz}$ and a sensitivity of $60 \mathrm{~V} / \mathrm{m} / \mathrm{s}$. Signals from the seismometers were recorded by Keisokugiken HKS-9550 data loggers, which are 24-bit recorders storing data at 200 samples per second per channel. We used data from 15 of the 16 seismic stations, discarding data from the station (gray circle in Fig. 1(b)) that had timing problems (M. Nakamoto, personal communication on 22 July, 2012). The directional sensitivity and resolution power of the array are described by the beam-forming array response at $2.5 \mathrm{~Hz}$ in Fig. 1(c). There was no distinct side lobe in the array response.

\section{Array Analysis of Continuous and Explosion Earthquake Records}

We used the semblance technique (Neidell and Taner, 1971) to measure apparent slownesses and back azimuths of the coherent wave phases that crossed the array. We calculated the semblance values for the selected array data at all the apparent slowness and back azimuth grid nodes. The position of the nodes with the maximum semblance value provides an estimate of the apparent slowness and back azimuth of the incoming wavefronts. The method works in the time domain, giving an advantage over techniques based on Fourier transforms in that the results are less sensitive to the length of the signal time window selected for the analysis (Almendros et al., 1999). This method requires much more computer time than frequency domain techniques, but less than the zero-lag cross-correlation technique (Frankel et al., 1991).

The semblance analysis was performed on the vertical component of the seismograms. After the waveform data were filtered using a bandpass filter of $2-3 \mathrm{~Hz}$, the semblance coefficient was calculated for a time window of $0.5 \mathrm{~s}$. This window length, determined after trying several values and observing the dependence of the results, was chosen because it guaranteed stable results and was greater than the one-cycle period at the middle of the dominant frequency band. We performed a continuous long-term array analysis, in which the time window started from the beginning of a 


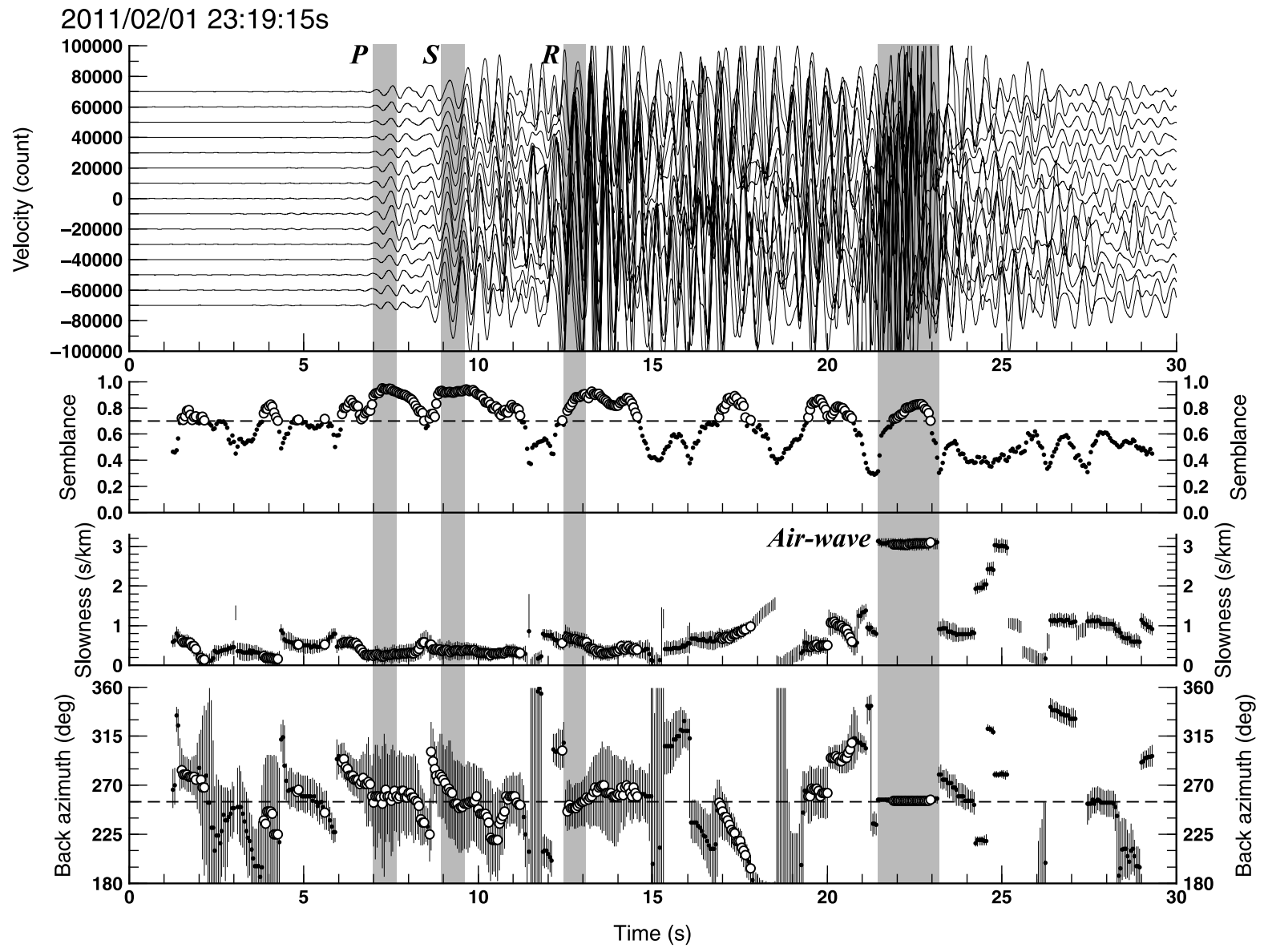

Fig. 3. Onset of an explosion earthquake at 23:19 JST on 1 February, 2011, in the 2-3 Hz band, recorded by the seismic array along with analytical results. The time axis starts at 23:19:15 JST. Shown from top to bottom are the seismograms of the 15 array channels, the semblance values, the apparent slowness, and the back azimuth. Solutions with semblance values greater than 0.7 (dashed line) are shown with open circles and the others with dots. Vertical lines with circles indicate the uncertainties of the solutions. The region in the apparent slowness and back azimuth panels with semblance values above 90 percent of the maximum provides an estimate of the uncertainty of the solution. The dashed line in the back azimuth panel represents the direction from the array center to the crater of Shinmoedake. The vertical gray bands indicate wave arrivals discussed in the text; the $P$ and $S$ arrivals are also shown in Fig. 2.

continuous waveform $1 \mathrm{~h}$ long and was moved successively by the length of $0.125 \mathrm{~s}$ until the end of the waveform, repeated for each $1 \mathrm{~h}$ continuous record in the observation period from 1 February to 30 September, 2011. We adopt the time shift length to reduce necessary computation time and to obtain enough time resolution for the wave propagation parameters.

The range of apparent slowness was searched from 0.05 to $3.00 \mathrm{~s} / \mathrm{km}$ in steps of $0.05 \mathrm{~s} / \mathrm{km}$, and the range of back azimuth was searched from $0^{\circ}$ to $355^{\circ}$ (measured clockwise from north) in $5^{\circ}$ steps over this continuous long-term analysis. We extracted the waveforms of nine explosion earthquakes that occurred during the observation period. For the analysis of these earthquakes, we adopted the same time window and time increment but finer step intervals: 0.01 $\mathrm{s} / \mathrm{km}$ steps for apparent slowness and $1^{\circ}$ steps for back azimuth.

\section{Seismic Signatures and Results of Array Anal- ysis of Explosion Earthquakes}

In Fig. 2, we present the initial portion of threecomponent waveforms and particle motions for an explosion earthquake at 23:19 JST on 1 February, 2011, at sta- tion KR07. These data were bandpass filtered at 2-3 Hz, a frequency band that includes the main energy band of the earthquake. At the signal onset (Fig. 2(a), interval marked $P)$, the particle motion was mainly radial in the verticalradial and radial-transverse domains (Fig. 2(b)), which suggest that $P$ waves with a near-horizontal ray direction were dominant in this time window. During the time window $2 \mathrm{~s}$ later (Fig. 2(a), interval marked $S$ ), particle motions in the vertical-transverse and radial-transverse domains (Fig. 2(c)) can be explained by $S V$ to $S H$ motion.

Sources of explosion earthquakes have been estimated to be beneath active craters at shallow depths, less than $2 \mathrm{~km}$ (e.g., Tameguri et al., 2002; Chouet et al., 2005; Ohminato et al., 2006). If we assume that the source depth of the explosion earthquakes at Shinmoedake is similar to the results of previous works for other volcanoes, comparison with explosion earthquakes and tremors is useful to evaluate the wave property and location of tremor, which will be described in the following sections. Here, we present our array analysis for the nine recorded explosion earthquakes, using data from vertical-component sensors. In verticalcomponent data, only $P, S V$, and Rayleigh waves are observable, while $S H$ and Love waves are excluded owing 


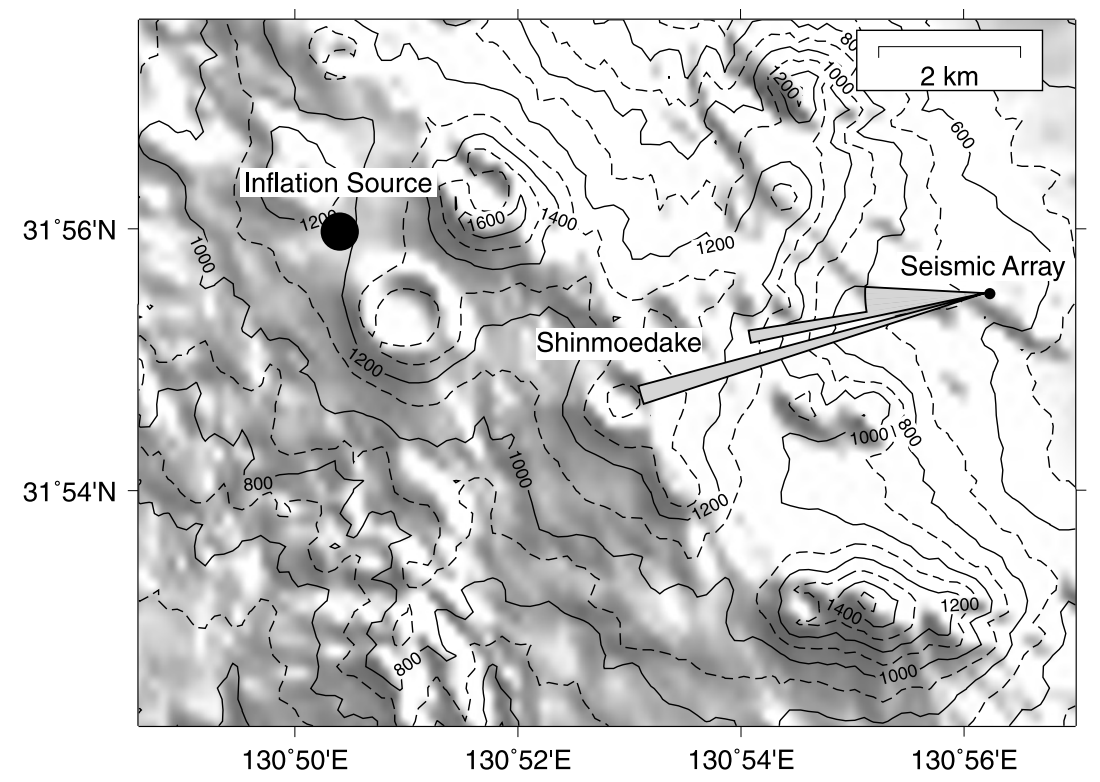

Fig. 4. Rose diagram of the back azimuths from the seismic array (shown as the small black dot) of the $P$ wave time window obtained for the nine recorded explosion earthquakes. The rose diagram has a $3^{\circ}$ interval. The back azimuths are those with maximum semblance values in the $P$ wave time window of each explosion earthquake. Most back azimuths point to Shinmoedake crater, and a few point slightly north of the crater. The inflation source estimated with GPS data (Japan Meteorological Agency, 2012b) is shown by the large black dot.

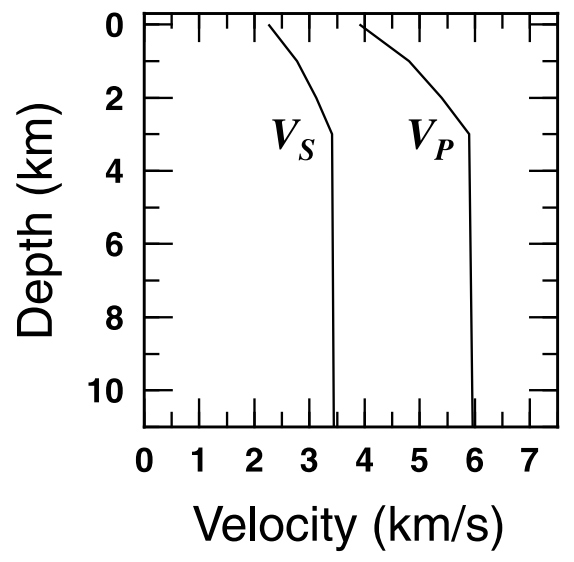

Fig. 5. One-dimensional velocity structures (J. Oikawa, personal communication on 12 July, 2012) used for calculating slowness values to estimate the depths of the explosion and tremor sources. The velocity structure is based on $P$ wave velocity structures (Tsutui et al., 1996; Nishi and Kagiyama, 2002). A Poisson's ratio of 0.25 is assumed.

to their predominantly horizontal motion. Figure 3 shows array results for the same explosion earthquake shown in Fig. 2. The first phases of the event between 7 and $7.7 \mathrm{~s}$, roughly corresponding to the $P$ wave time window in Fig. 2(a), were characterized by slowness values around $0.21-0.28 \mathrm{~s} / \mathrm{km}$. The corresponding apparent velocity, approximately $3.6-4.8 \mathrm{~km} / \mathrm{s}$, was consistent with $P$ waves impinging at a large incident angle. The phases in the time window between 9 and $9.7 \mathrm{~s}$, roughly corresponding to the $S$ time window in Fig. 2(a), were characterized by slowness values around $0.35-0.39 \mathrm{~s} / \mathrm{km}$. The corresponding apparent velocity, approximately $2.6-2.9 \mathrm{~km} / \mathrm{s}$, was consistent with $S$ waves impinging at a large incident angle. The back azimuths during both of these time windows pointed roughly toward Shinmoedake crater around $255^{\circ}$. About $3.5 \mathrm{~s}$ after the $S$ wave arrival, slowness increased to $0.7 \mathrm{~s} / \mathrm{km}$ and the back azimuth again was around $255^{\circ}$, coincident with the arrival of Rayleigh waves (Fig. 3). An acoustic phase arriving at $15-16 \mathrm{~s}$ had a slowness of $3.1 \mathrm{~s} / \mathrm{km}$, corresponding to an apparent velocity of $0.32 \mathrm{~km} / \mathrm{s}$, and a back azimuth of $255^{\circ}$.

For all nine explosion earthquakes, back azimuths of $P$ waves, when maximum semblance values in the $P$ wave window met or exceeded a threshold value of 0.7 (Fig. 4), pointed mostly directly toward Shinmoedake crater or slightly north of it. The corresponding apparent slowness ranged from $0.20 \mathrm{~s} / \mathrm{km}$ to $0.37 \mathrm{~s} / \mathrm{km}$. The mean apparent slowness was $0.30 \mathrm{~s} / \mathrm{km}$ and the mean back azimuth was $260^{\circ}$ for the explosion earthquakes.

Hypocenters for the explosion earthquakes, determined by using the conventional method, are at a depth of $-0.5-$ $1 \mathrm{~km}$ below sea level beneath the crater (Japan Meteorological Agency, 2012a). The apparent slowness for $P$ waves was calculated from these hypocenters using a onedimensional velocity structure (Fig. 5) as $0.21-0.23 \mathrm{~s} / \mathrm{km}$, which is within the apparent slowness range of $0.21-0.28$ $\mathrm{s} / \mathrm{km}$ determined from our array observations. As a reference, this velocity structure is based on results of the seismic exploration in 1994 using artificial seismic sources around Kirishima volcano (Tsutui et al., 1996; Nishi and Kagiyama, 2002). It is possible that the explosion earthquake sources are shallower than the hypocenters determined by the conventional method, because the observed apparent slownesses are greater than the calculated ones.

\section{Results of Continuous Long-Term Array Anal- yses and Detection of Weak Continuous Tremor}

Our continuous long-term array analysis also detected tremor episodes during the observation period from 1 February to 30 September. Since the tremor of each episode 


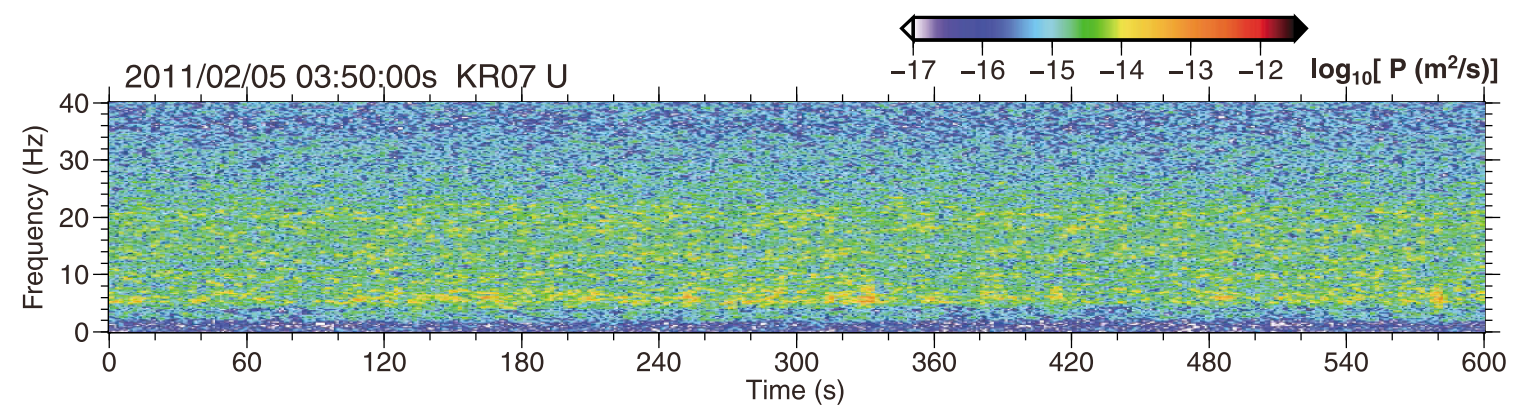

Fig. 6. Spectrogram of 10 minutes of a weak continuous tremor recorded by vertical seismometer of KR07. The window's starting time is 03:50 JST on 5 February, 2011, which is the same as Fig. 7. The spectrogram was calculated for a $4 \mathrm{~s}$ window $75 \%$ overlap using the FFT.

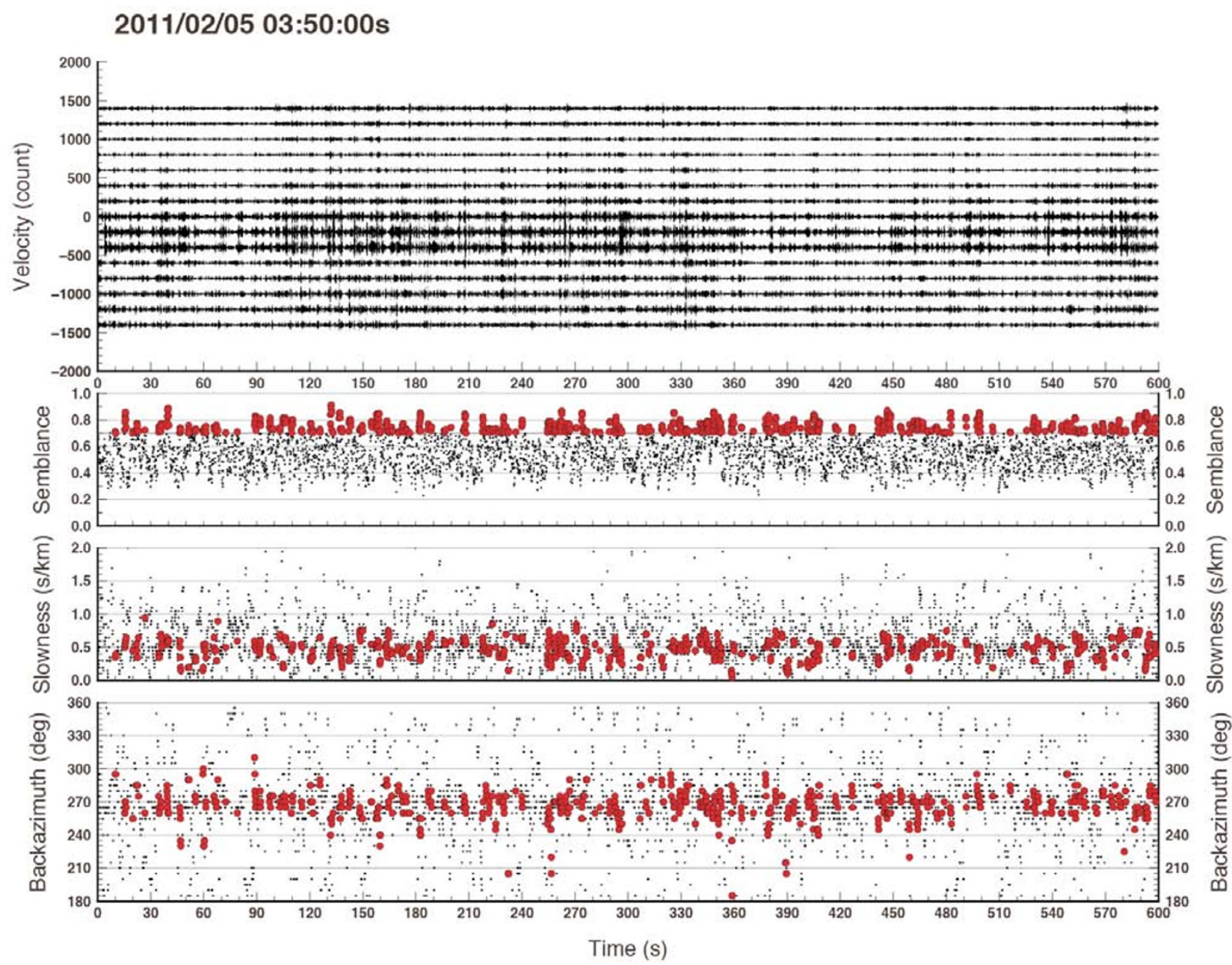

Fig. 7. Record and analysis of a weak continuous tremor in the $600 \mathrm{~s}$ time window starting at 03:50 JST on 5 February, 2011. Shown from top to bottom are seismograms of the 15 array channels, the semblance values, the apparent slowness, and the back azimuth. Solutions with semblance values greater than 0.7 are shown with open red circles and the others with black dots. The line in the semblance panel is the 0.7 threshold.

continued for several days and has small amplitudes (100$200 \mathrm{~nm} / \mathrm{s}$ ), we call the tremor episode a weak continuous tremor. The durations and periods of the tremor episodes will be specifically described later. Figure 6 shows a 10min-long spectrogram of the vertical component at station KR07 during a period of volcanic tremor. There is neither a clear dominant frequency nor a harmonic nature in the spectrogram. The spectral energy distributes between 2 and 24 $\mathrm{Hz}$ and has no clear temporal variation. Although there is no clear spectral peak, relatively stronger energy is seen around
$6 \mathrm{~Hz}$ through the 10-min-long records. Figure 7 shows 10 min of the array record and its analysis during a period of volcanic tremor, showing coherent phases with semblance values greater than or equal to 0.7 . The amplitude of the tremor was two orders of magnitude smaller than that of the explosion earthquake (Fig. 3) and an order of magnitude smaller than that of the harmonic tremor episode on 2 February, 2011 (Kyushu University, 2012). The apparent slownesses in Fig. 7 were clustered within the range of $0.2-$ $0.8 \mathrm{~s} / \mathrm{km}$, suggesting that a mix of body $(P-S)$ and surface 


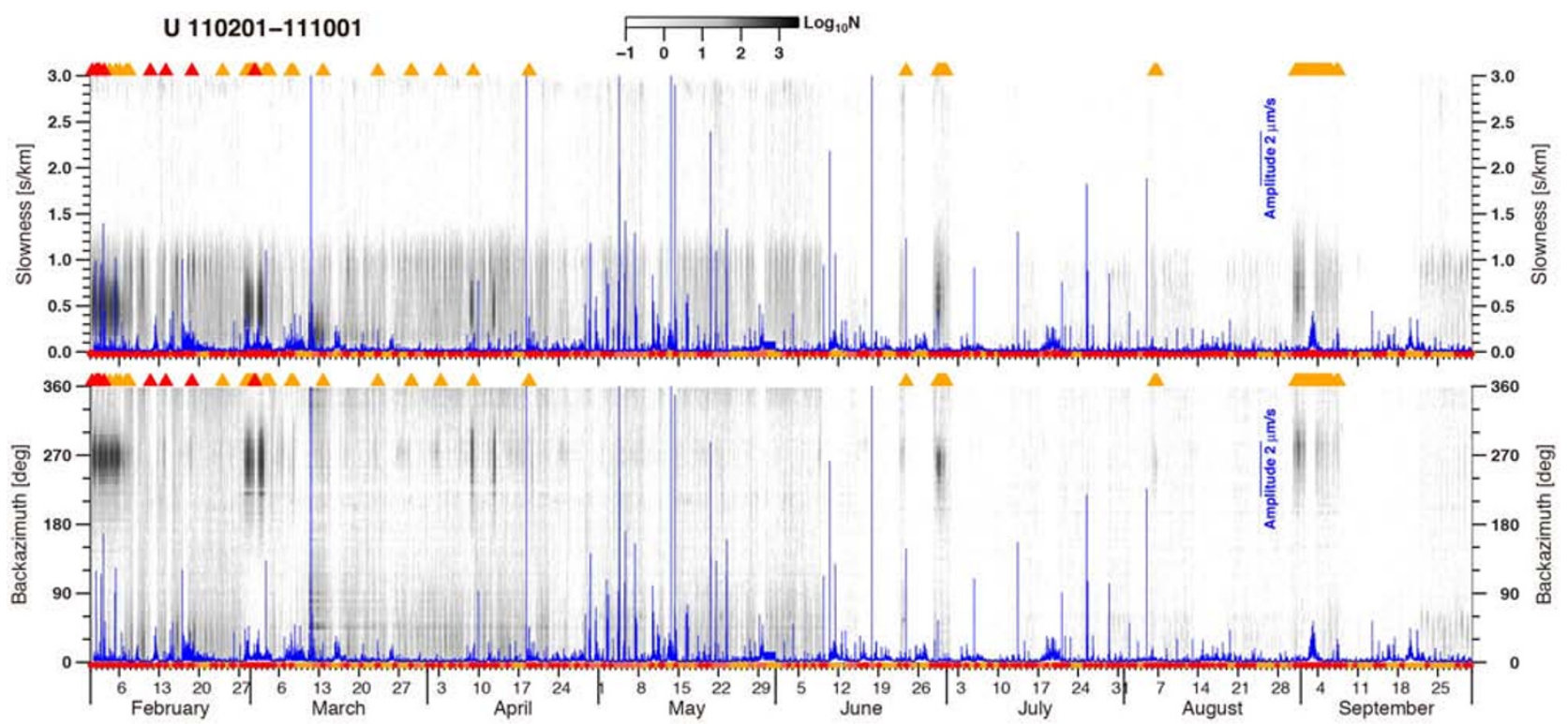

Fig. 8. Temporal evolution during the study period of apparent slowness and back azimuth derived from the array analysis of vertical components. The gray scale maps the hourly histograms of slowness $\left(0.05 \mathrm{~s} / \mathrm{km}\right.$ grid interval) and back azimuth $\left(5^{\circ}\right.$ grid interval) measurements. Blue lines show the maximum amplitude of the vertical component in every $1 \mathrm{~h}$ window. Red and orange triangles show the times of explosive and non-explosive eruptions, respectively. The red and orange solid circles near the time axes show the times of volcanic tremor and low-frequency volcano earthquakes, respectively.

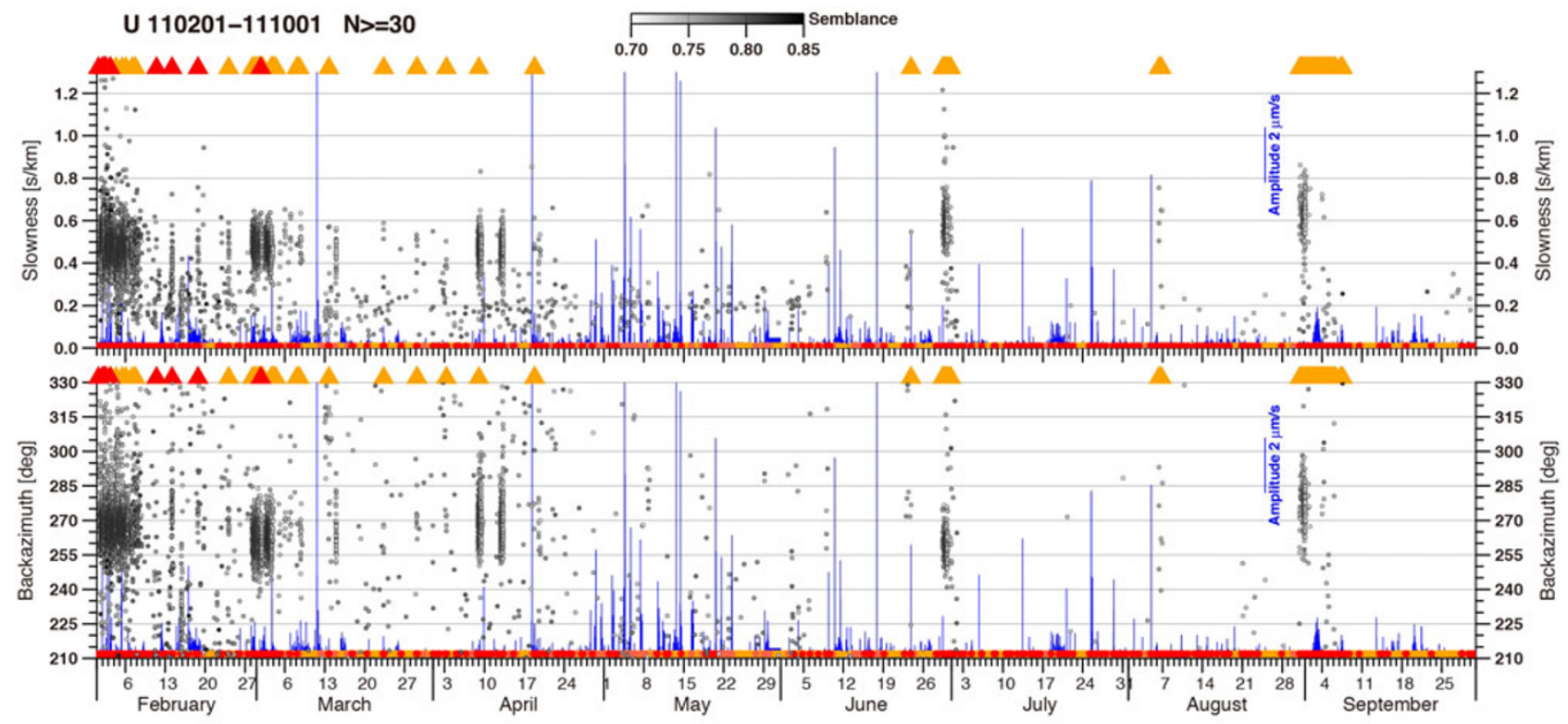

Fig. 9. Temporal evolution of high-semblance data on average apparent slowness and back azimuth derived from the array analysis of vertical components. Circles show the average apparent slownesses or back azimuths that are calculated from two horizontal slowness values within 1-min time windows. Averages are calculated only for windows in which slowness values with semblance greater than or equal to 0.7 occurred 30 times or more. The gray scale inside the circles shows the average semblance value. Other symbols are the same as in Fig. 8.

waves came from a shallow source, because the range is consistent with the ranges of the apparent slowness of $P, S$ and surface waves of the explosion earthquakes. The back azimuths were clustered around the west direction $\left(270^{\circ}\right)$ within the range $240^{\circ}-290^{\circ}$, which is north of the crater direction $\left(255^{\circ}\right)$.

Figure 8 shows the frequency distribution of apparent slowness and back azimuth values for each hour during the whole analyzed period from February to September 2011. High frequencies occurred in early February and in late
February to early March for both slowness and back azimuth. Slightly high frequencies occurred in late June and in late August to early September. The apparent slownesses and back azimuth with high frequency are clustered within the ranges of $0.2-0.8 \mathrm{~s} / \mathrm{km}$ and $240^{\circ}-290^{\circ}$, respectively, and the same as those for the weak continuous tremor (Figs. 6 and 7), suggesting that the weak continuous tremor also occurred in these periods. These periods correspond to explosive and non-explosive eruptions, although there were a few eruptions when no tremor was detected in middle and late 
March.

Figure 9 shows the time-dependent distribution of the average apparent slownesses and back azimuths for every 1 min window in the analyzed period in which the average semblance values was equal to, or greater than, 0.7 for the window. The average apparent slownesses were clustered within the range of $0.35-0.65 \mathrm{~s} / \mathrm{km}$ between February and April; however, in June and August the average slownesses were around $0.45-0.8 \mathrm{~s} / \mathrm{km}$, suggesting that the tremor source was shallower than it was earlier. The average back azimuths were clustered around $250^{\circ}-280^{\circ}$ from February to March, then shifted slightly to $255^{\circ}-290^{\circ}$ in April, to $250^{\circ}-270^{\circ}$ in late June, and to $260^{\circ}-300^{\circ}$ at the end of August. This progression suggests that the tremor source moved from slightly north of the crater to the north and then back in the period from February to August 2011.

\section{Source Locations of Explosion Earthquakes and Weak Continuous Tremor}

We estimated the source location of the explosion earthquakes and the weak continuous tremor using a procedure based on the probabilistic inversion of the horizontal slowness vectors $\left(S_{X}, S_{Y}\right)$ observed at the array site. The reliability of the source location is expressed by a spatial probabilistic density function (PDF) (Saccorotti et al., 1998; Saccorotti and Del Pezzo, 2000; La Rocca et al., 2004). The maximum probability for the source location is associated with the minima of a misfit function, defined through the weighted differences between the observed slowness vector $S_{\text {obs }}$ and the vectors $S_{\text {cal }}$ calculated by ray tracing in the one-dimensional velocity structure shown in Fig. 5. The observed slowness $\boldsymbol{S}_{\text {obs }}$ was obtained from our estimated apparent slownesses and back azimuths. For each grid node $\boldsymbol{x}$ of the model space, we traced direct rays to the array location, thus computing the slowness vector $\boldsymbol{S}_{\text {cal }}(\boldsymbol{x})$. Assuming a Gaussian error distribution of slowness with a standard deviation of $\sigma$, the conditional PDF (likelihood function) is expressed as

$$
L(\boldsymbol{S} \mid \boldsymbol{x})=\frac{1}{\sqrt{2 \pi} \sigma} \exp ^{-\left(\boldsymbol{S}_{\mathrm{obs}}-\boldsymbol{S}_{\mathrm{cal}}(\boldsymbol{x})\right)^{2} / 2 \sigma^{2}}
$$

The standard deviation $\sigma$ includes the uncertainties in the estimate of observed and predicted slowness vector components. Although the predicted uncertainty depends on the velocity structure (Saccorotti and Del Pezzo, 2000), we only consider here the standard deviation for the observed slowness. We calculate the standard deviations for the observed slownesses in the $P$ and $S$ time windows of the explosion earthquake, as shown in Fig. 3, to be 0.025 and 0.04 $\mathrm{s} / \mathrm{km}$, respectively. For safety's sake, we adopt twice the standard deviations as $\sigma_{P}=0.05 \mathrm{~s} / \mathrm{km}$ and $\sigma_{S}=0.08$ $\mathrm{s} / \mathrm{km}$, which are slightly larger than those used for locating explosion earthquake sources at Stromboli (Saccorotti et al., 1998; Saccorotti and Del Pezzo, 2000; La Rocca et al., 2004).

As described in Section 4, the means of the apparent slownesses and back azimuths for $P$ waves of the explosion earthquakes were $0.3 \mathrm{~s} / \mathrm{km}$ and $260^{\circ}$, respectively, which we used to locate their sources. As shown in Section 5, the apparent slownesses and back azimuths of tremor corresponded to a mix of body and surface waves. It is difficult to discriminate phases of tremor for assigning wave types to the estimated apparent slowness. We assumed an apparent slowness of $0.4 \mathrm{~s} / \mathrm{km}$, corresponding to $S$ waves, which is comparable to the slowness of $0.35-0.39 \mathrm{~s} / \mathrm{km}$ for $S$ waves from the explosion earthquakes (Fig. 3). We adopted the back azimuth of $265^{\circ}$ for locating the source of the tremor.

The spatial likelihood distributions are shown in Figs. 10 and 11 for the explosion earthquakes and tremor, respectively. The likelihood becomes large along the ray path of waves that approach the array in the direction estimated by the array analysis. For the explosion earthquake source, the area of highest likelihood includes Shinmoedake crater (Fig. 10). The E-W and N-S vertical cross-sections of the spatial likelihood distribution that intersect the crater show that high likelihoods occur just below the crater at depths of $-0.5-1 \mathrm{~km}$ above sea level. This depth range is shallower than the depths of explosion earthquakes $(-0.5-1 \mathrm{~km}$ below sea level) determined from first arrival times (Japan Meteorological Agency, 2012a). The high-likelihood area for the tremor source (Fig. 11) is located between the volcanoes Karakunidake, Ohnamiike, and Shinmoedake and between Shinmoedake and the inflation source inferred from geodetic data (Japan Meteorological Agency, 2012b). The E-W and N-S vertical cross-sections intersect at a point between Karakunidake and Shinmoedake, where the high-likelihood maximum is at depths between $1 \mathrm{~km}$ below sea level and 1 $\mathrm{km}$ above sea level.

As seen in Figs. 7-9, the propagation parameters of the tremor were somewhat scattered. The causes of the scatter may include the action of multiple nonisotropic sources, measurement errors associated with departure from the plane-wave assumption, severe ray bending associated with medium heterogeneities, and focusing effects resulting from free-surface interactions related to the volcano topography (e.g., Ripperger et al., 2003). Assessing all these effects would require inverting the estimated propagation parameters using theoretical slowness fields obtained from wavefield simulations in three-dimensional, heterogeneous media, and including the free-surface effect of topography (e.g., Almendros et al., 2001a). However, that task is unfeasible without information on the velocity structure at a scale comparable to the wavelengths analyzed in this study.

\section{Discussion and Conclusions}

Based on knowledge of previously published studies and the results of this study, we can construct a possible configuration of the volcano-hydrothermal system of the Kirishima group (Fig. 12). Magnetotelluric observations have revealed a widespread low-resistivity layer in the central and northwestern volcanoes of the Kirishima group, such as Shinmoedake, beneath a more resistive surface layer about $100 \mathrm{~m}$ thick (Kagiyama, 1994; Utada et al., 1994; Kagiyama et al., 1996). The low-resistivity layer extends down to the depth of sea level below the central and northwestern part of the Kirishima group, but is much shallower beneath the southeastern Kirishima volcanoes such as Ohachi and Takachihonomine. It is interpreted as a watersaturated porous layer, consistent with hydrothermal activ- 


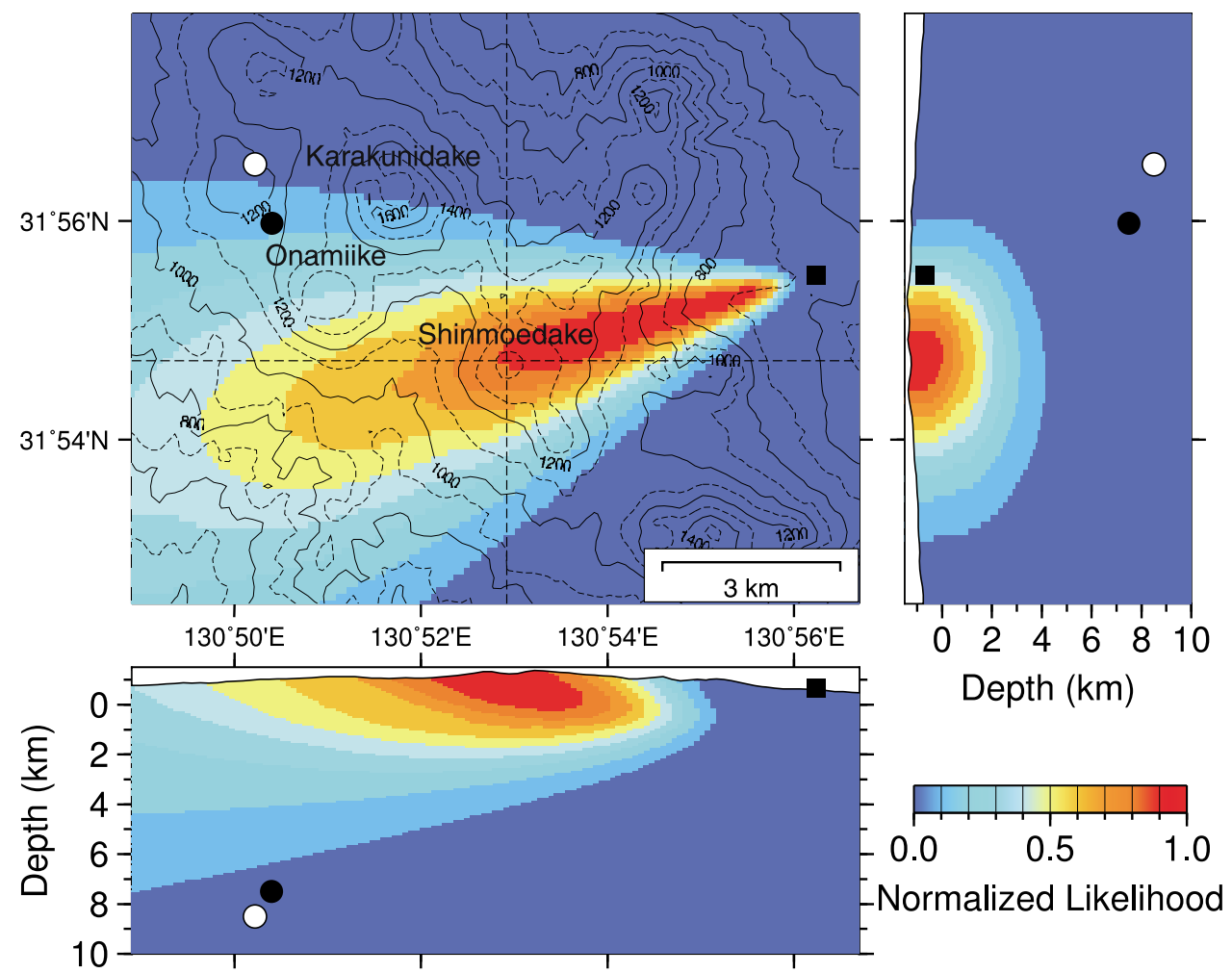

Fig. 10. Horizontal and vertical cross-sections of the likelihood distribution for the source location of the explosion earthquakes. Vertical exaggeration is 0.5. Depths are shown relative to sea level. Solid squares show the location of the seismic array. Solid and open circles represent inflation and deflation pressure sources, respectively, estimated from GPS data (Japan Meteorological Agency, 2012b). The map represents a horizontal cross-section at sea level; dashed lines are the locations of the vertical cross-sections. The $P$ wave apparent slowness and back azimuth were assumed to be $0.3 \mathrm{~s} / \mathrm{km}$ and $260^{\circ}$, respectively, for likelihood calculations. The standard error for the observed slowness was assumed to be $0.05 \mathrm{~s} / \mathrm{km}$.

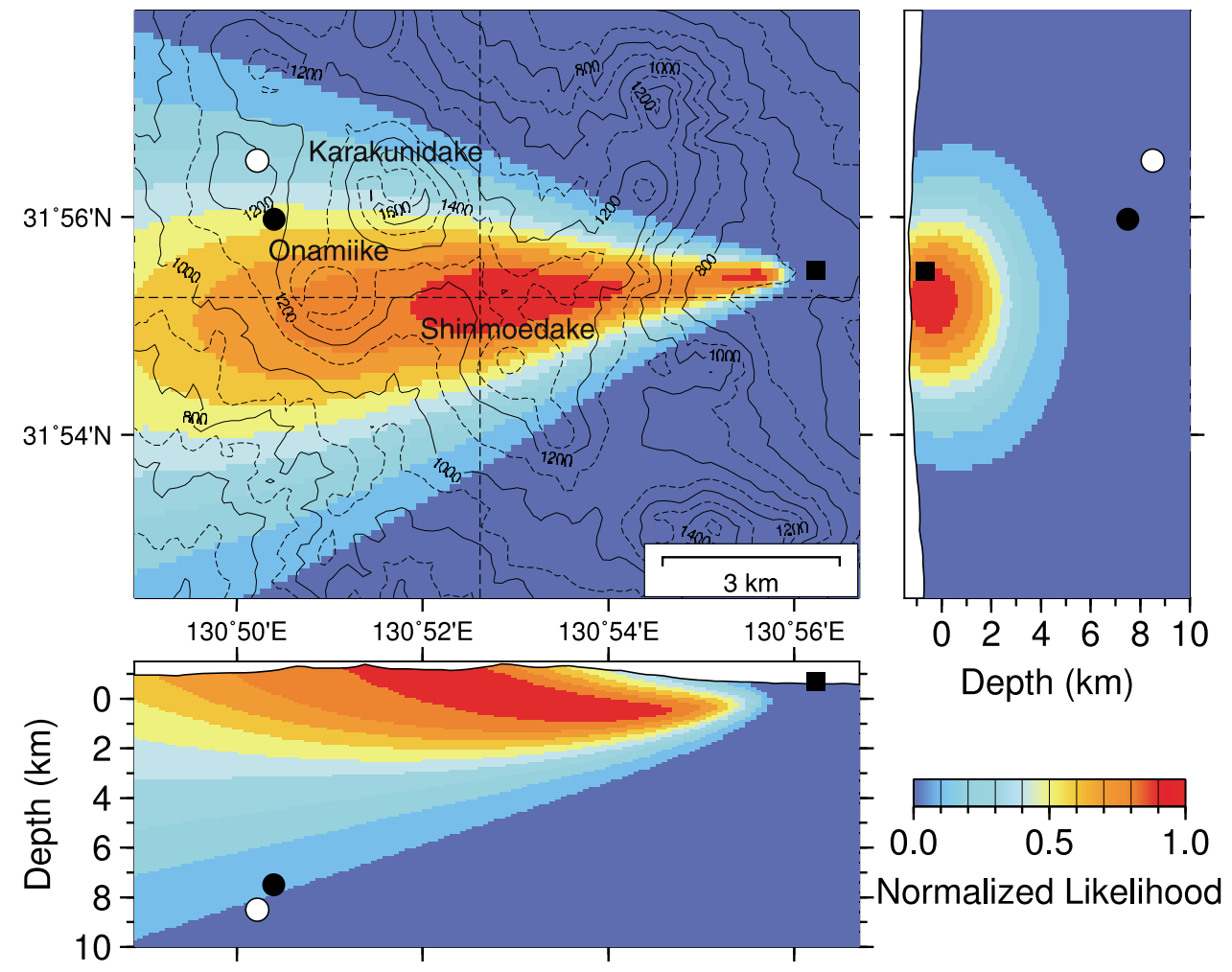

Fig. 11. Horizontal and vertical cross-sections of the likelihood distribution for the source location of the continuous tremor. Graphical details are the same as in Fig. 10. The $S$ wave apparent slowness and back azimuth were assumed to be $0.4 \mathrm{~s} / \mathrm{km}$ and $265^{\circ}$, respectively, for likelihood calculations. The standard error for the observed slowness was assumed to be $0.08 \mathrm{~s} / \mathrm{km}$. 


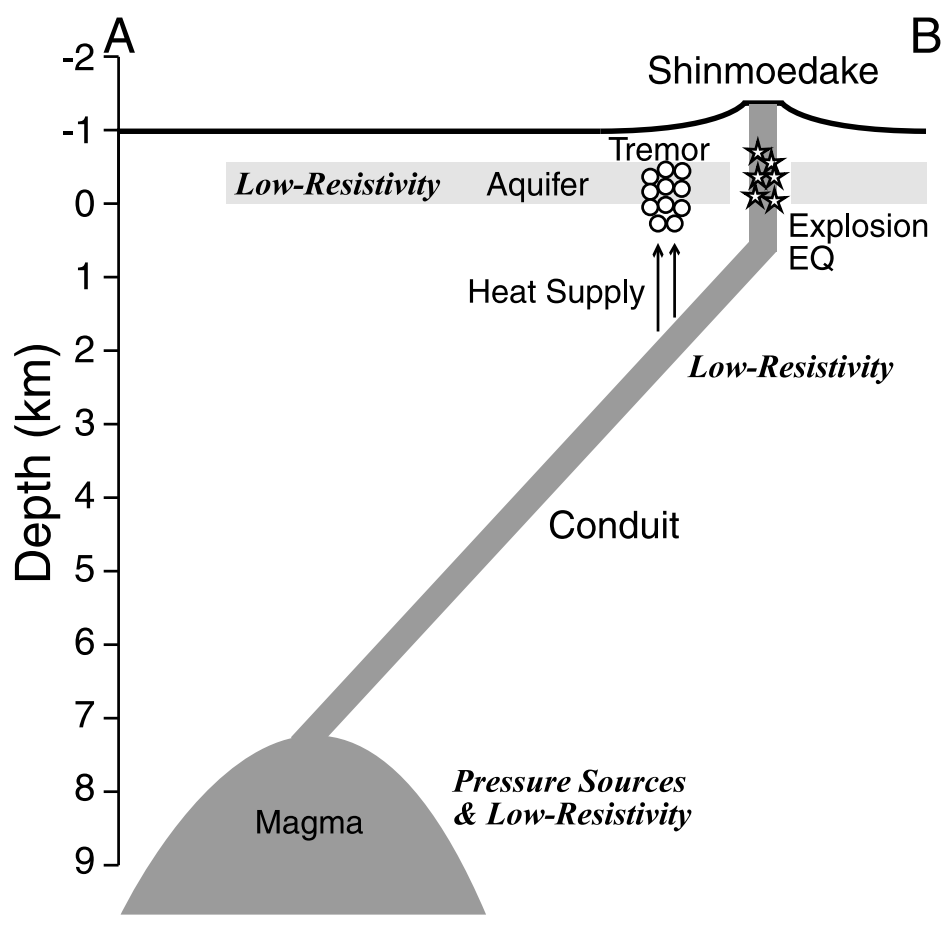

Fig. 12. Possible configuration of the volcano-hydrothermal system beneath the study area, which is along the approximate orientation of the cross-section AB (Fig. 1). Light grey areas show the aquifer layer, which corresponds to the low-resistivity layer suggested by magnetotelluric observations (Kagiyama, 1994; Utada et al., 1994; Kagiyama et al., 1996). Dark gray areas show the magma reservoir and pathway to Shinmoedake, which correspond to the pressure sources (Japan Meteorological Agency, 2012b) and the low-resistivity layers. Open circles and stars show locations of tremor and explosion earthquakes, respectively. More details are given in the texts.

ity, and it plays an important role in controlling eruptions and associated eruptive phenomena through interaction of magma and water in the saturated layer (Kagiyama, 1994; Kagiyama et al., 1996). A deep low-resistivity layer appears about $10 \mathrm{~km}$ below the surface in the central and northwestern parts of the Kirishima group, but is shallower beneath Shinmoedake at elevations of 2-3 km below sea level (Utada et al., 1994; Kagiyama et al., 1996). The pressure sources estimated by GPS data (Japan Meteorological Agency, 2012b) roughly correspond to the deep lowresistivity layer, suggesting a magma source. Kagiyama (1994) proposed that a path for rising magma or volcanic gas exists between the deep and shallow low-resistivity layers because this region matches the locations of an earthquake swarm before the small eruption of Shinmoedake in 1991 and the deflation source after the eruption. Ohba et al. (1997) investigated chemical and isotopic composition of hot spring waters and fumarolic gases from the Kirishima group. They elucidate the hydrothermal system, where a hypothetical parent fluid emitted from a heat source (probably molten magma) is supposed to mix with meteoric water forming thermal water beneath Shinmoedake.

As shown in Section 6, a high-likelihood region for the tremor source is shallower than $1.5 \mathrm{~km}$ below the northern part of Shinmoedake (Fig. 11). This region corresponds to the low-resistivity layer, suggesting that hydrothermal processes are more plausible than magmatic processes as the generating mechanism of the tremor. The magma transport path would be between the estimated pressure source region and the summit of Shinmoedake, because that is where the significant deflation of the volcano associated with the 26
January sub-Plinian eruption occurred (Japan Meteorological Agency, 2012b). The volatiles that exsolved from the magma would enter the water-saturated porous layer. Furthermore, the magma may encounter groundwater and supply some of its heat to the hydrothermal system. Several models for the tremor source involve fluids-water, magma, exsolved volatiles, or all three (e.g., Kumagai and Chouet, 2000; Fujita et al., 2004; Iwamura and Kaneshima, 2005). Tremor caused by boiling of water is generally weaker than tremor involving magma movement (McNutt, 1996). Therefore, the weak continuous tremor may originate in the heated water-saturated layer.

Volcanic tremor frequently occurs as a precursor of eruptions as well as accompanying eruptions. A clear relationship between tremor and eruptions is seen in our study period from February to September 2011 (Figs. 8 and 9), although the relationship is unclear in middle and late March 2011, when seismic waves from the 11 March, 2011, Tohoku earthquake and its large aftershocks affected the continuous long-term array analysis. The synchronization of weak continuous tremor and eruptions suggests that hydrothermal activity is also activated by magma transport during eruption periods.

In conclusion, we used a single seismic array to locate weak continuous tremor in the Kirishima group and evaluate its activity. However, the deployment of several seismic arrays compensates for the limited quality of individual slowness measurements and possible structural effects on the wave field, enabling successful estimates of the locations of volcanic tremor and earthquakes with emergent initial phases (Métaxian et al., 2002). Therefore, a multi-array 
analysis is required to better determine the source locations of the tremor and emergent earthquakes. A probabilistic approach using a three-dimensional (3D) velocity structure is efficient in constraining source locations of explosion earthquakes and tremor (Almendros et al., 2001a, b; La Rocca et al., 2004). The next stage of seismic array observation at volcanoes, then, would use multiple arrays and a 3D velocity structure for the array analysis. Furthermore, the procedure described in this study, which requires limited computing time, can be adapted to real-time volcano monitoring, in which data from a seismic array are transmitted from seismometers to a central office in real time. These advances will contribute to our understanding of magmatic systems and our ability to forecast eruptive activity.

Acknowledgments. Manami Nakamoto informed us of the timing problem for a station in our seismic array. Jun Oikawa kindly provided the one-dimensional velocity structure used in the Kirishima Volcano Observatory, Earthquake Research Institute, University of Tokyo. Tsuyoshi Watanabe calculated the positions of seismometers using GPS data. We are grateful to Takao Ohminato, an anonymous reviewer, and the guest editor Motoo Ukawa for reviewing our manuscript and valuable comments. This work was partially supported by the Japanese Society for the Promotion of Science Institutional Program for Young Researcher Overseas Visits. This work was partly completed at the University of Bristol during a six-month stay by $\mathrm{HN}$ as a visiting fellow in 2011. This study was supported by a Grant-in-Aid for Special Purposes (Grant Number 22900001) from the Ministry of Education, Culture, Sports, Science and Technology.

\section{References}

Almendros, J., J. M. Ibáñez, G. Alguacil, and E. Del Pezzo, Array analysis using circular-wave-front geometry: An application to locate the nearby seismo-volcanic source, Geophys. J. Int., 136, 159-170, doi:10.1046/j.1365-246X.1999.00699.x, 1999.

Almendros, J., B. Chouet, and P. Dawson, Spatial extent of a hydrothermal system at Kilauea Volcano, Hawaii, determined from array analyses of shallow long-period seismicity 1. Method, J. Geophys. Res., 106, 13,565-13,580, doi:10.1029/2001JB000310, 2001a.

Almendros, J., B. Chouet, and P. Dawson, Spatial extent of a hydrothermal system at Kilauea Volcano, Hawaii, determined from array analyses of shallow long-period seismicity 2. Results, J. Geophys. Res., 106, 13,581-13,597, doi:10.1029/2001JB000309, 2001b.

Chouet, B. A., Dynamics of a fluid-driven crack in three dimensions by the finite difference method, J. Geophys. Res., 91, 13,967-13,992, doi:10.1029/JB091iB14p13967, 1986.

Chouet, B. A., Long-period volcano seismicity: Its source and use in eruption forecasting, Nature, 380, 309-316, doi:10.1038/380309a0, 1996.

Chouet, B., G. Saccorotti, M. Martini, P. Dawson, G. De Luca, G. Milana, and R. Scarpa, Source and path effects in the wave fields of tremor and explosions at Stromboli Volcano, Italy, J. Geophys. Res., 102, 15,12915,150, doi:10.1029/97JB00953, 1997.

Chouet, B., P. Dawson, and A. Arciniega-Ceballos, Source mechanism of Vulcanian degassing at Popocatépetl Volcano, Mexico, determined from waveform inversions of very long period signals, J. Geophys. Res., 110, B07301, doi:10.1029/2004JB003524, 2005.

Di Lieto, B., G. Saccorotti, L. Zuccarello, M. La Rocca, and R. Scarpa, Continuous tracking of volcanic tremor at Mount Etna, Italy, Geophys. J. Int., 169, 699-705, doi:10.1111/j.1365-246X.2007.03316.x, 2007.

Frankel, A., S. Hough, P. Friberg, and R. Busby, Observation of Loma Prieta aftershocks from a dense array in Sunnyvale, California, Bull. Seismol. Soc. Am., 81, 1900-1992, 1991.

Fujita, E., M. Ukawa, and E. Yamamoto, Subsurface cyclic magma sill expansions in the 2000 Miyakejima volcano eruption: Possibility of two-phase flow oscillation, J. Geophys. Res., 109, B04205, doi:10.1029/2003JB002556, 2004.

Furumoto, M., T. Kunitomo, H. Inoue, I. Yamada, K. Yamaoka, A. Ikami, and Y. Fukao, Twin sources of high-frequency volcanic tremor of Izu-Oshima Volcano, Japan, Geophys. Res. Lett., 17, 25-27,
doi:10.1029/GL017i001p00025, 1990.

Goldstein, P. and B. A. Chouet, Array measurements and modelling sources of shallow volcanic tremor at Kilauea Volcano, Hawaii, J. Geophys. Res., 99, 2637-2652, doi:10.1029/93JB02639, 1994.

Hashimoto, A., T. Shimbori, and K. Fukui, Tephra fall simulation for the eruptions at Mt. Shinmoe-dake during 26-27 January 2011 with JMANHM, SOLA, 8, 37-40, doi:10.2151/sola.2012-010, 2012.

Imura, R., Eruptive history of the Kirishima volcano during the past 22,000 years, Geogr. Rep. Tokyo Metrop. Univ., 27, 71-89, 1992.

Imura, R., Geology of Kirishima Volcano, Bull. Earthq. Res. Inst. Univ. Tokyo, 69, 189-209, 1994 (in Japanese with English abstract and figure captions).

Iwamura, K. and S. Kaneshima, Numerical simulation of the steam-water flow instability as a mechanism of long-period ground vibrations at geothermal areas, Geophys. J. Int., 163, 833-851. doi:10.1111/j.1365246X.2005.02749.x, 2005.

Japan Meteorological Agency, Volcanic activity of Kirhisimayama volcano, February 2011-May 2011, Rep. Coord. Comm. Predict. Volcan. Erup., 109, 139-167, 2012a (in Japanese with English figure captions).

Japan Meteorological Agency, Ground deformation in Shinmoe-dake, Kirishima volcano, Rep. Coord. Comm. Predict. Volcan. Erup., 109, 168-172, 2012b (in Japanese with English figure captions).

Jellinek, A. M. and D. Bercovici, Seismic tremors and magma wagging during explosive volcanism, Nature, 470, 522-525, doi:10.1038/nature09828, 2011.

Julian, B. R., Volcanic tremor: Nonlinear excitation by fluid flow, J. Geophys. Res., 99, 11,859-11,878, doi:10.1029/93JB03129, 1994.

Kagiyama, T., Significance of investigations on the structure of Kirishima Volcanoes, Bull. Earthq. Res. Inst. Univ. Tokyo, 69, 177-188, 1994 (in Japanese with English abstract and figure captions).

Kagiyama, T., H. Utada, M. Uyeshima, F. Masutani, W. Kanda, Y. Tanaka, H. Masuda, H. Murakami, I. Shiozaki, M. Ichiki, T. Yukutake, T. Mogi, K. Amita, N. Oshiman, and M. Mishina, Resistivity structure of the central and the southeastern part of Kirishima Volcanoes, Bull. Volcanol. Soc. Jpn., 41(5), 215-225, 1996 (in Japanese with English abstract and figure captions).

Kanamori, H., J. W. Given, and T. Lay, Analysis of seismic body waves excited by the Mount St. Helens eruption of May 18, 1980, J. Geophys. Res., 89, 1856-1866, doi:10.1029/JB089iB03p01856, 1984.

Konstantinou, K. I. and V. Schlindwein, Nature, wavefield properties and source mechanisms of volcanic tremor: A review, J. Volcanol. Geotherm. Res., 119, 161-187, doi:10.1016/S0377-0273(02)00311-6, 2002.

Kumagai, H. and B. A. Chouet, Acoustic properties of a crack containing magmatic or hydrothermal fluids, J. Geophys. Res., 105, 25,493-25,512, doi:10.1029/2000JB900273, 2000 .

Kyushu University, Volcanic activity report of Kirishimayama (Shinmoedake), Rep. Coord. Comm. Predict. Volcan. Erup., 108, 247-259, 2012 (in Japanese with English figure captions).

La Rocca, M., G. Saccorotti, E. Del Pezzo, and J. Ibanez, Probabilistic source location of explosion quakes at Strombili volcano estimated with double array data, J. Volcanol. Geotherm. Res., 131, 123-142, doi:10.1016/S0377-0273(03)00321-4, 2004.

McNutt, S. R., Seismic monitoring and eruption forecasting of volcanoes: A review of the state-of-the-art and case histories, in Monitoring and Mitigation of Volcanic Hazards, edited by Scarpa and Tilling, pp. 100 146, Springer, Berlin, 1996.

Métaxian, J.-P., P. Lesage, and B. Valette, Locating sources of volcanic tremor and emergent events by seismic triangulation: Application to Arenal volcano, Costa Rica, J. Geophys. Res., 107(B10), 2243, doi:10.1029/2001JB000559, 2002.

Neidell, N. S. and M. T. Taner, Semblance and other coherency measures for multichannel data, Geophysics, 36, 482-497, doi:10.1190/1.1440186, 1971.

Nishi, K. and T. Kagiyama, Three-dimensional seismic velocity structure and focal distribution of Kirishima Volcano, Abst. Japan Geosci. Union 2002 Meeting, V032-034, 2002.

Nishimura, T. and H. Hamaguchi, Scaling law of volcanic explosion earthquake, Geophys. Res. Lett., 20, 2479-2482, doi:10.1029/93GL02793, 1993.

Ohba, T., K. Nogami, and J. Hirabayashi, Hydrothermal system of Kirishima volcanic area inferred from the chemical and isotopic composition of spring waters and fumarolic gases, Bull. Volcanol. Soc. Jpn., 42(1), 1-15, 1997.

Ohminato, T., M. Takeo, H. Kumagai, T. Yamashina, J. Oikawa, E. Koyama, H. Tsuji, and T. Urabe, Vulcanian eruptions with dominant 
single force components observed during the Asama 2004 volcanic activity in Japan, Earth Planets Space, 58, 583-593, 2006.

Palo, M., J. M. Ibáñez, M. Cisneros, M. Bretón, E. Del Pezzo, E. Ocaña, J. Orozco-Rojas, and A. M. Posadas, Analysis of the seismic wavefield properties of volcanic explosions at Volcán de Colima, México: Insights into the source mechanism, Geophys. J. Int., 177, 1383-1398, doi:10.1111/j.1365-246X.2009.04134.x, 2009.

Ripperger, J., H. Igel, and J. Wasserman, Seismic wave simulation in the presence of real volcano topography, J. Volcanol. Geotherm. Res., 128, 31-44, doi:10.1016/S0377-0273(03)00245-2, 2003.

Saccorotti, G. and E. Del Pezzo, A probabilistic approach to the inversion of data from a seismic array aid its application to volcanic signals, Geophys. J. Int., 143, 249-261, doi:10.1046/j.1365-246x.2000.00252.x, 2000.

Saccorotti, G., B. Chouet, M. Martini, and R. Scarpa, Bayesian statics applied to the location of the source of explosions at Stromboli Volcano, Italy, Bull. Seismol. Soc. Am., 88, 1099-1111, 1998.

Tameguri, T., M. Iguchi, and K. Ishihara, Mechanism of explosive eruptions from moment tensor analyses of explosion earthquakes at Sakurajima Volcano, Japan, Bull. Volcanol. Soc. Jpn., 47(4), 197-215, 2002.

Tsutsui, T., T. Kagiyama, H. Mikada, Y. Morita, T. Matsushima, M. Iguchi, J. Oikawa, K. Yamaoka, H. Kumagai, Y. Nishimura, H. Miyamachi, T.
Watanabe, T. Nishimura, A. Takagi, K. Yamamoto, H. Hamaguchi, H. Okada, T. Maekawa, H. Oshima, S. Ueki, K. Hashimoto, K. Nida, S. Shigehara, H. Nakamichi, K. Shiomi, H. Nakahara, S. Aoki, H. Aochi, Y. Ida, H. Watanabe, S. Onizawa, N. Osada, N. Gyoda, H. Tsuji, M. Yamaguchi, F. Masutani, I. NIshidomi, T. Inoue, W. Ito, T. Okuda, R. Miyajima, M. Shibata, T. Kito, K. Tsuruga, M. Maeda, H. Shimizu, N. Matsuo, K. Umakoshi, K. Uchida, T. Okumura, M. Shibata, Y. Sudo, S. Yoshikawa, T. Yamada, T. Mori, Y. Matsumoto, T. Takayama, M. Nendrasto, S. Hirano, H. Yakiwara, H. Ueno, K. Ishihara, H. Mori, J. Hirabayashi, T. Oba, K. Nogami, T. Mori, M. Sato, and S. Tominaga, Seismic velocity structure beneath Kirishima Volcanoes with differential analysis of explosion experiment, Bull. Volcanol. Soc. Jpn., 41(5), 227-241, 1996 (in Japanese with English abstract and figure captions). Utada, H., T. Kagiyama, and EM Research Group for Kirishima Volcano, Deep resistivity structure of Kirishima Volcano (I), Bull. Earthq. Res. Inst. Univ. Tokyo, 69, 241-255, 1994 (in Japanese with English abstract and figure captions).

H. Nakamichi (e-mail: nakamiti@svo.dpri.kyoto-u.ac.jp), Y. Yamanaka, T. Terakawa, S. Horikawa, T. Okuda, and F. Yamazaki 